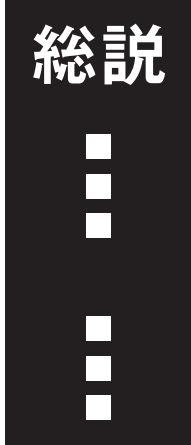

\title{
軸索誘導因子は “がん微小環境制御因子”として機能する
}

\section{中山 寛尚 ${ }^{1,2)}$, 東山 繁樹 ${ }^{2}$}

要約 : 脳の発生過程において神経細胞は適切な位置に 配置され, 複雑かつ緻密な神経回路網を形成していく. その過程で軸索誘導因子と呼ばれる，セマフォリン (semaphorin), ネトリン (netrin), スリット (slit), エ フリン（ephrin）に代表される4種の因子とそのレセ プターが精密な神経回路形成に極めて重要な役割を 担っている，軸索誘導因子は，その作用として神経軸 索を誘引または反発する性質を有しており, 軸索を適 切な方向に伸長させて, 標的の神経細胞に到達するた めのガイダンス因子として機能している。 その後，さ らなる機能解析によって，これらの因子は神経細胞の みならず血管内皮細胞，がん細胞，免疫細胞など様々 な細胞に働きかけ，多様な機能を持ち合わせていること が分かってきた，たとえばセマフォリン 3F（SEMA3F） は，神経軸索伸長を阻害する反発因子であると同時に， グリオーマ U87MG 細胞の遊走・浸潤を阻害すること, 血管内皮細胞の遊走を阻害して血管新生を抑制する因 子であることが分かってきた。一方で，軸索伸長を誘 引するネトリン-1（netrin-1）は, U87MG 細胞の遊走 • 浸潤を惹起するとともに，血管新生を誘導して転移を 誘発する因子であることが明らかとなった。近年では， netrin-1 が CD4 陽性 T細胞に対して遊走を惹起すること が分かり，炎症免疫応答においても重要な役割を担っ ていることが分かってきた。 以上の知見から我々は軸 索誘導因子が，がんとその周辺環境（微小血管ネット ワーク, 細胞外基質や炎症など), いわゆる『がん微小 環境』の制御因子であると考えている。がん微小環境 は，がん幹細胞を形成・維持することによって，がん の再発や薬剤抵抗性を生み出す要因となることや，が 几細胞の浸潤・転移を誘発する分子機構の一端を担っ ている。よって, 軸索誘導因子のがん微小環境への影
響を精査してその役割を解明することによって，新た ながん治療薬の開発あるいは治療戦略が提示できるも のと考えている.

\section{1.はじめに}

生体において神経と血管は全く異なる役割を果たし ているが，両者には様々な共通点が存在している。 今 から 500 年ほど前に解剖学者 Andreas Vesalius は, 人 体における神経と血管の詳細な構造を描いており, 両 者の走行や分岐パターンが極めて似通っていることを 示している $(1,2)$. ミクロレベルで比較してみると, 神経細胞と血管内皮細胞はそれぞれネットワークを構 築して機能している。たとえば, 神経細胞は精密な神 経回路ネットワークを構築するために, 神経細胞が突 起を出して軸索を伸長し, 標的の神経細胞の樹状突起 と連絡してシナプスを形成する。一方で血管内皮細胞 も創傷治癒の過程や子宮内膜では, 既存の血管から新 たな血管が出芽, 分岐して血管網が再構築されて血管 ネットワークが形成される（血管新生, angiogenesis). 細胞の詳細な部位を観察してみると, 神経細胞の先端 には成長円錐と呼ばれる部位があり，これがセンサー の役割を担って軸索を適切な方向，場所へと誘導して いく，成長円錐には，軸索誘導因子のレセプターが発 現しており，軸索を誘引する因子，または反発させる 因子を感知して方向性を決定している。この構造体は 血管新生過程の血管内皮細胞の先端にも同様に観察さ れ tip cell と呼ばれている. 血管内皮増殖因子 (vascular endothelial growth factor：VEGF）に代表される血管 新生因子によって，既存の血管から血管内皮細胞が出 芽，遊走して，その先端の tip cell が誘引方向へと新た な血管網を構築していく(3)。また血管新生阻害因子

キーワード：軸索誘導因子，セマフォリン，ネトリン，血管新生，がんの転移

1) 広島国際大学 保健医療学部 医療技術学科 臨床検査学専攻（下739-2695 広島県東広島市黒瀬学園台 555-36)

2) 愛媛大学 プロテオサイエンスセンター 細胞増殖・腫瘍制御部門（テ791-0295 愛媛県東温市志津川）

E-mail: hironao@hs.hirokoku-u.ac.jp＼cjkstart原稿受領日：2017 年 9 月 1 日, 依頼原稿

Title: Novel function of axon guidance molecule as a regulator of tumor microenvironment

Author: Hironao Nakayama, Shigeki Higashiyama 
（endostatin, angiostatin など）もいくつか同定されて おり，血管新生の適正なバランスが制御されている (4)。このように, 神経と血管は由来や機能は全く異 なるが，マクロやミクロレベルでの構造，形態が似て いること，両者ともにリガンドとレセプターによって ネットワーク構築が制御されていること, さらに，そ の制御機構には正と負のシグナルが存在してバランス を維持していることが次々に明らかとなり, 神経と血 管のクロストークが注目されるようになってきた.

このような中, Dr. Michael Klagsbrun（Harvard Medical School）グループが，軸索誘導因子セマフォ リンレセプターである neuropilin-1（NRP1）が，血管 内皮細胞やがん細胞に発現し, 血管新生因子 VEGF の レセプターとなることを明らかにした (5). 非チロシ ンキナーゼレセプターである NRP1 はVEGF レセプ ターとともに $\mathrm{VEGF}_{165}\left(\mathrm{VEGF}_{121}\right.$ は NRP1 と結合しな い）に結合し，血管内皮細胞の遊走や増殖を活性化す るのに重要な分子であることを突き止めた。 この発見 を皮切りに, NRP1 のリガンドであるセマフォリン $3 \mathrm{~A}$ (SEMA3A または collapsin-1) が, $\mathrm{VEGF}_{165}$ と NRP1 へ の結合を競合的に阻害して血管新生を阻害すること (6), 逆にVEGF が交連神経軸索の誘導因子となるこ とが報告され(7), 血管と神経のネットワークが共通 する分子によって制御されていることが次々に実証さ れた。

その後さらなる解析が進み, 軸索誘導因子またはそ のレセプターが, 種々のがん細胞で発現していること が明らかとなり, その発現量が, がんの悪性度や腫瘍 血管新生に大きな影響を与えていることが分かってき た (詳細は下記参照)。その結果, 軸索誘導因子とその レセプター群が神経，血管制御にとどまらず，がん， 免疫, 炎症, 骨代謝など様々な生体機能や病態形成に

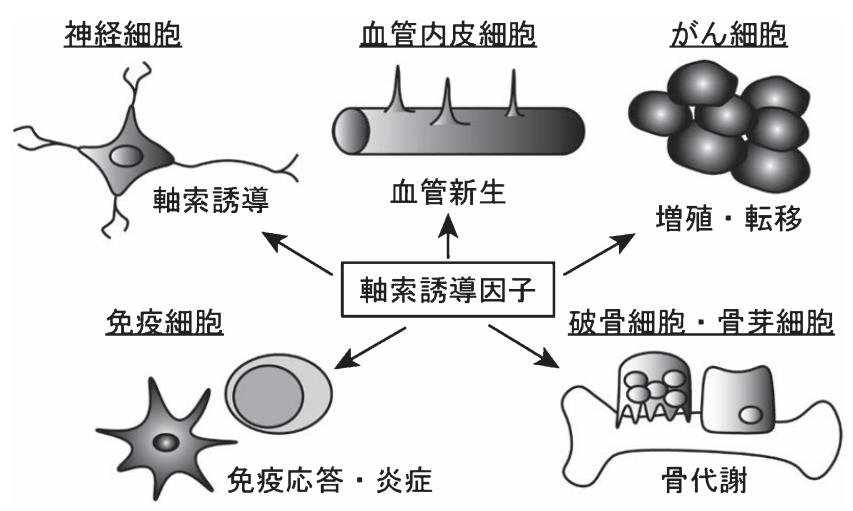

図 1 軸索誘導因子は様々な細胞に作用する

神経回路形成に重要な因子として同定された軸索誘導因子とそのレセプ ター群は, 様々な細胞に発現し作用することが分かってきた. 生理的な 役割のみならず,がんを含む様々な疾患に関与している.
関わっていることが分かってきた（図 1 参照)。本稿 では，セマフォリンとネトリンファミリーに着目し， がん, 血管新生, 免疫における我々の最新の知見を紹 介して, 軸索誘導因子のがん微小環境制御因子として の新たな機能を概説する.

\section{2. セマフォリン}

セマフォリンはもともと, 発生期において神経軸 索の反発因子として同定された(8)。哺乳類では 20 種のセマフォリンが同定されクラス $3 \sim 7$ の 5 グ ループに分類されている $(9,10)$. クラス 3 セマフォ リンは分泌型, クラス 4 6 6膜貫通型, クラス 7 は glycophosphatidylinositol（GPI）アンカー型として産 生される。受容体にはプレキシンファミリー（9 種類） が知られており A〜Dの 4 クラスに分別されている. クラス 3 セマフォリンはプレキシンとの結合に加えて NRP（NRP1，NRP2）レセプターとの結合が必要とさ れている.

セマフォリンと NRP レセプターが血管新生制御に 重要な働きをしていることが明らかになるにつれて $(5,6)$, がんの進展にも梁く関わっていることが分 かってきた. セマフォリン 3B (SEMA3B) と SEMA3F は, 肺小細胞がんで欠損していた染色体 3p21.3 の領 域から見つかってきた分子であることから，がん抑制 因子である可能性が報告された $(11,12)$ 。また, 種々 のがん細胞株（メラノーマ，膀胱がん，前立腺がん） の中でも転移能を有している株では, SEMA3F の発現 が低下していることが確認された(13)，ヒトメラノー マ細胞移植マウスを使った解析では, SEMA3F が，が ん内部に浸潤してくる血管, リンパ管を阻害すること, がん細胞のアポトーシスを誘導すること, 他臓器への 転移を阻害する効果が認められた(13)。近年, 我々は 乳児血管腫 (infantile hemangioma) 細胞株においてセ マフォリンレセプター発現解析を行い, プレキシン D1 と NRP2 が高発現していることを突き止めた。 そ のリガンドである SEMA3E または SEMA3F を血管腫 細胞に処理したところ，細胞遊走や細胞増殖が抑制さ れた. SEMA3E または SEMA3F 処理によって 3 次元 培養下 VEGF 刺激による血管腫細胞の出芽 (sprouting) の阻害が認められたため, 血管腫の新規治療法として の可能性を報告した(14)。このようにセマフォリンと がんの関係が次々に明らかになってきたため, 我々は セマフォリンがどのような分子メカニズムによってが ん細胞に影響をもたらすのか検討を行った。 


\section{3. セマフォリンの分子メカニズム解析}

\section{1）細胞骨格アクチン}

セマフォリンの作用機序は神経細胞を中心に解析が 進んできた. SEMA3Aが軸索先端の成長円錐に作用 すると, 細胞骨格アクチンの重合を阻害して葉状仮足 (lamellipodia) が形成されず伸長ができなくなる。こ の現象は血管内皮細胞に打いても同様に観察され, SEMA3AがNRP1 依存的にアクチン重合を阻害して葉 状仮足形成を阻害することによって細胞遊走が抑制さ れる(6). さらに SEMA3F の解析から, メラノーマ細胞 やグリオーマ細胞など，がん細胞においても同様な機 構があることが分かってきた $(13,15)$. SEMA3F の分 子メカニズム解析は Shimizu らによって詳細に報告さ れている(15). SEMA3F はレセプターであるNRP2 とプ レキシン A1 に結合すると, 細胞内に局在する p190Rho GTPase activation protein（p190RhoGAP）をリン酸化 する．活性化されたp190RhoGAPは small GTPase RhoA を不活化 (GTPから GDP 型に置換) する. SEMA3F によってRhoAが不活化されることによって下流の Rho キナーゼが不活化され, その結果, アクチン脱重 合因子である cofilin を脱リン酸化（活性化）してアク チンを脱重合させることによって細胞骨格が崩壊する. さらに Shimizu らは, SEMA3F は NRP2 とプレキシン A1 レセプターに結合するとチロシンキナーゼ ABL2 を呼び寄せて，p190RhoGAPを活性化することを見出 した，このデータを基に我々は，ABL2 阻害薬イマチ ニブ（グリベック）が, SEMA3A と SEMA3F のアク チン重合阻害効果を抑制することを明らかにした。つ まり，イマチニブがセマフォリンのアンタゴニストに なることを示唆するデータである(16).

\section{2) AKT-mTOR シグナル}

我々は, がん細胞における SEMA3F の細胞内シグナ ル伝達経路を明らかにするため, グリオーマ U87MG 細胞を用いて検討を行った. SEMA3Fによって変動 するキナーゼを網羅的に探索するため Phospho-Kinase Antibody Array（R\&D）を用いた。 その結果, SEMA3F 処理によって AKT, ERK, mTORのリン酸化が抑制 されていることが明らかとなった。 ウエスタンブ ロッティングによって, AKT-mTOR シグナル経路に 関わるリン酸化タンパク質を検討したところ, mTOR 下流分子である S6K およびS6 のリン酸化も抑制され ていた。 また AKT上流因子の PI-3Kの活性化も SEMA3Fによって抑制されていた. SEMA3F の効果 は U87MG 細胞のみならず, 血管内皮細胞, T 細胞に おいても確認されたことから, SEMA3F は様々な細胞
に対して PI-3K/AKT/mTOR シグナルを抑制すること が明らかとなった。ささら SEMA3F と PI-3K制御因子 phosphatase and tensin homologue deleted on chromosome ten (PTEN) との関わりを検討した. 血管内皮細胞 HUVEC を使って免疫沈降したところ PTEN が NRP2 レセプターと結合していることが明らかとなり， PTENノックダウンによって SEMA3F の抑制効果が見 られなくなったことから, SEMA3FによるAKTmTORシグナル抑制にはPTENが関与していることが 示唆された。 しかしながら, 我々が用いたがん細胞 (U87MG，U251，Jurkat 細胞）では，PTEN が欠損し ているにも関わらず SEMA3F は AKT-mTOR シグナル を抑制した，詳細は不明であるが, SEMA3F シグナル には, PTEN非依存的にAKT-mTORシグナルを制御す るメカニズムが存在していることが明らかとなった (17).

\section{3） mTOR 複合体}

mTOR は raptor, rictor どのコファクター分子と 結合し，それぞれ mTOR complex 1 (mTORC1), mTORC2 複合体を形成し, 細胞周期, 増殖, 生存, ア ポトーシスなど様々な役割を担っている(18)。そこで SEMA3F 処理後, mTOR 抗体を用いて免疫沈降を行い, mTOR と結合する raptor (mTORC1) あるいは rictor （mTORC2）をそれぞれ検出し mTOR 複合体形成に与え る影響を検討した。その結果, SEMA3F は mTORCl お よび mTORC2 両方の複合体形成を阻害した. mTORC1 阻害薬ラパマイシンあるいは mTORC1/C2 阻害薬 Torin 1 は, S6K リン酸化を抑制する。 しかし, ラパマ イシンはAKT のリン酸化を増加させる。 これはラパ マイシンがS6Kによる negative feedback (AKTの上流 を阻害する経路)を抑制するからである。一方で Torin 1 は mTORC2 も同時に抑制するためAKTのリ ン酸化を抑制することが可能である. SEMA3F と mTOR 阻害薬の効果を比較すると, SEMA3F は AKT と S6K ともに抑制すること, また SEMA3F はラパマ イシンによって上昇した AKT のリン酸化も抑制する ことから Torin 1 と同様に mTORC2 を抑制しているこ とが考えられる。 この可能性を検証するため, AKTの 活性型変異体 (2DAKT) を細胞に導入し（mTORC1 シ グナルを活性化), SEMA3F の効果を検討したところ, 2DAKT 導入細胞では, SEMA3F は S6K 活性を阻害す ることができなかった。つまり SEMA3F は，まず mTORC2 活性を抑制し, その後 AKT-mTORC1 シグナ ルを抑制することが明らかになった（図 2 参照).

mTORC2 は細胞骨格制御に重要な役割を担ってお り (18), Torin 1 または rictor-siRNA 処理 (mTORC2 阻 


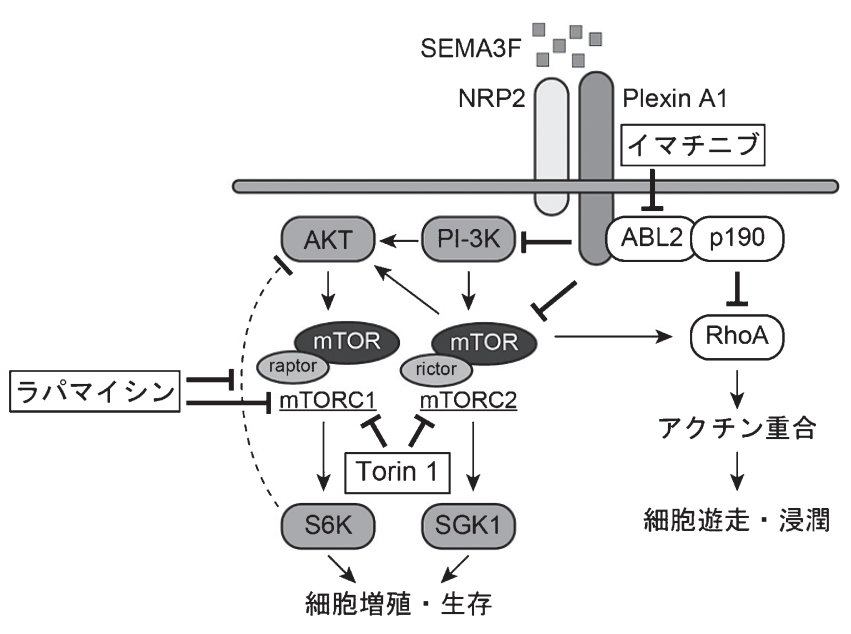

図 2 SEMA3F の細胞内シグナル解析

SEMA3F はレセプターを介してPI-3K と mTORC2 を抑制する. アク チン重合はABL2/p190RhoGAP または mTORC2 を介して阻害される。 イマチニブは ABL2 を阻害するため SEMA3F のアンタゴニストとして 働く. MTOR 阻害薬ラパマイシン, Torin 1の作用点を示した。（文献 15 17 参照)

害）によってRhoAが不活化されアクチン重合が阻害 される。一方で, rictorノックダウン細胞に SEMA3F を処理したところ，さらにアクチン重合を阻害したこ とから, SEMA3FによるRhoA不活化メカニズムには ABL2/p190RhoGAP と mTORC2 の両経路が関わって いることが示唆された(17).

\section{4）がん細胞增殖と血管新生}

SEMA3F による抗腫瘍効果を検証するため, がん細 胞移植後に SEMA3F を発現するアデノウィルスを投 与して，がんに対する効果を評価した。 ヌードマウス に U87MG 細胞を皮下移植し, 2 日後にコントロール あるいは SEMA3F を発現するアデノウィルスを尾静 脈より投与した。アアデノウィルスは肝臟でクッパー細 胞によって取り込まれると, そこから SEMA3Fを分泌 して血中へと供給される. SEMA3Fの発現はマウス 肝蔵および血中で上昇したことを確認している，その 結果, 皮下移植した腫瘍のサイズはSEMA3Fを発現す るアデノウィルス投与によって有意に抑制され，腫瘍 内部の血管新生も抑制されていた，さらに腫瘍を摘出 して細胞内シグナルを見てみると, in vitro で観察され たように AKT-mTOR シグナルが抑制されていた.

mTORC1 阻害薬であるラパマイシンは抗腫瘍薬と して期待されていたが，免疫抑制作用による副作用や， AKT シグナルの活性化によって十分な効果が得られ なかった。一方で SEMA3F は mTORC1, mTORC2 両 複合体を阻害するため, より効果的に AKT-mTOR シ グナルを抑制し，抗腫瘍効果を発揮できると考えてい る。また, SEMA3Fをラパマイシン（あるいはその誘 導体）と併用することによって，ラパマイシンを低濃
度で副作用が少なく安全に使用可能と考えており, 臨 床応用を目指した基礎的データの収集を行っている (17).

\section{4. ネトリン}

ネトリンファミリーは分泌型（netrin-1, netrin-3, netrin-4）と膜結合型（netrin-G1, netrin-G2）として産生 される.レセプターは少なくとも 7 種類 uncoordinated 5A-D (UNC5A-D), deleted in colorectal cancer (DCC), neogenin, down syndrome cell adhesion molecule (DSCAM) が知られている (19)。 ネトリンファミリー は軸索誘導因子として脊髄交連神経細胞の軸索を誘引 する因子として同定された，その後, 神経以外での役 割も次々に明らかになってきた。 Netrin-1 は血管内皮 細胞の增殖, 遊走を誘導し創傷治癒を促すことや, ゼ ブラフィッシュやマウスの検討から, 新たな血管の出 芽や虚血モデルにおける神経障害を緩和する役割が報 告されている $(20,21)$ ，一方で別のグループからは $u n c 5 b$ ノックアウトマウスやゼブラフィッシュでは血 管の分岐の増加や異常な血管の走行が見られたことか ら, netrin-1 はUNC5B レセプターを介して血管新生を 抑制的に制御していると報告している $(22,23)$ 。この ように, netrin-1 は血管新生に対して正と負の制御機 能をもっており, 濃度, 標的細胞の違い, 発現してい るレセプターのパターンなど, 様々な要因によって機 能が異なると考えられている。近年では，ネトリン ファミリーが動脈硬化や糖尿病におけるマクロファー ジの制御に関わっており, 炎症や免疫応答に重要な分 子であることが報告された $(24)$ ，我々は，がん，血管 新生, 免疫応答に着目し netrin-1 の分子機構解析を 行ってきた。本稿では, 脳腫瘍モデルの解析を中心に netrin-1 の機能を紹介する.

\section{1）がんと転移}

小児脳腫瘍である髄芽腫（medulloblastoma）は，小 脳に発症する悪性腫瘍である，米国に扔ける報告では 転移，播種を伴わないタイプでは 5 年生存率が 80 $90 \%$ と良好である一方で，浸潤性を有し播種転移する 場合では 5 年生存率が $30 \%$ に低下する。 また, 髄芽腫 細胞の浸潤・転移能が放射線, 化学治療に対する感受 性も含め予後に大きく影響することが分かっているた め, 髄芽腫細胞の浸潤能の程度を予測すること, 抑制 することが診断・治療方針・予後・治療に非常に重要 であると考えられている。

我々は Dr. Edward Smith（Harvard Medical School） 研究室と共同で髄芽腫患者尿サンプルを用いてバイオ マーカー探索を行っていた，我々が興味を持っていた 
A

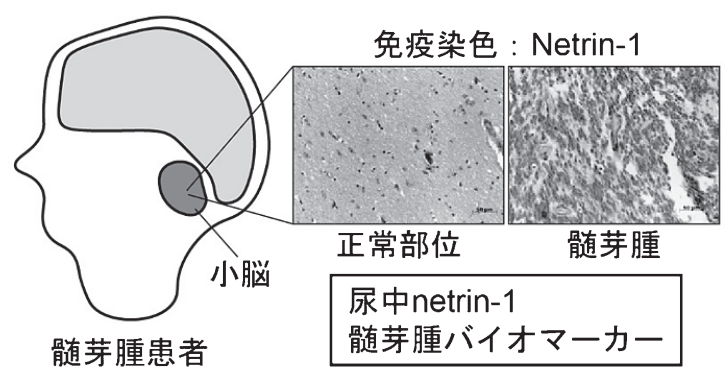

B

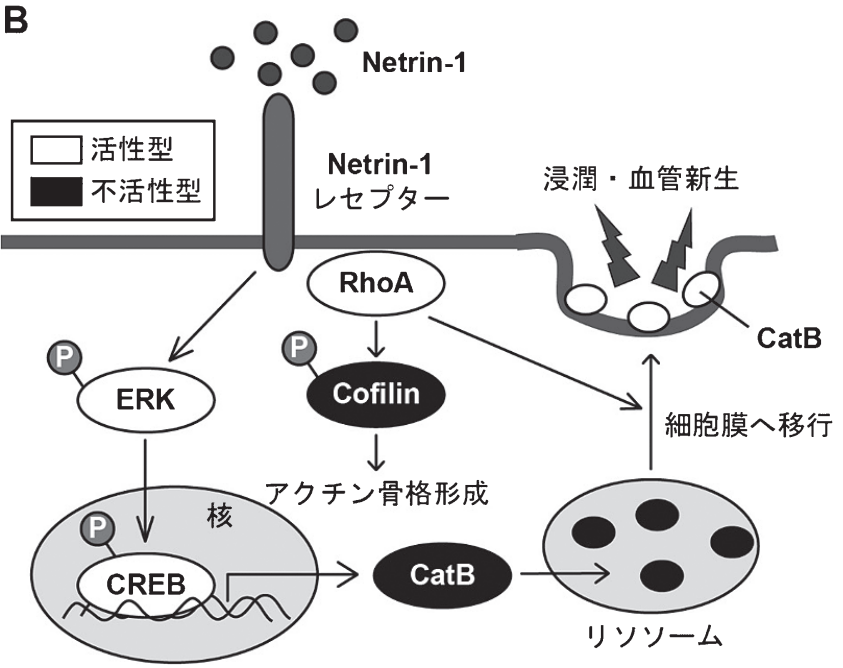

図 3 グリオーマおよび鲠芽腫における netrin-1 の作用機序

A : 尿中 netrin-1 は咀芽腫の有無, 転移, 予後を予測するバイオマー カーとして活用できる. B：細胞内 netrin-1 シグナルを示した. (文献 25, 26 参照)

軸索誘導因子をスクリーニングした結果，健常尿サン プルに比べて髄芽腫患者では netrin-1 濃度が上昇して いた，尿中 netrin-1 レベルは髄芽腫患者の悪性度（転 移の程度）と相関すること, 髄芽腫摘出後に低下する ことが分かった。髄芽腫組織切片においても免疫染色 法で netrin-1の上昇が確認された．以上のデータから， 尿中 netrin-1 が髄芽腫の有無, 浸潤の程度, 治療経過 を予測するバイオマーカーとして有用なことを報告し た（図 3A 参照）(25).

脳腫瘍グリオーマにおいても netrin-1 の効果を検証 している。ヒトグリオーマ U87MG 細胞に netrin-1 を 処理すると細胞遊走と浸潤が促進されることから， netrin-1 を遺伝子導入した U87MG 細胞を樹立してヌー ドマウス皮下に移植を行った。腫瘍が直径 $10 \mathrm{~mm} に$ 達したところで腫瘍を摘出し, さらにその 1 カ月後に リンパ節を摘出して免疫染色を行い転移の有無を確認 した．親株 U87MG 細胞では, 移植部位近傍リンパ節 には約 $60 \%$ で転移が確認されたが，遠位リンパ節では 転移は見られなかった。しかし netrin-1 過剩発現株で は，近位および遠位リンパ節で $100 \%$ 転移が確認され た。つまり， netrin-1 ががんの転移を強力に促進する 因子であることが明らかとなった(26).

\section{2）血管新生}

Netrin-1 が血管新生に与える影響を検討するため, マウス脳組織から血管内皮細胞を単離し実験に用いた. Netrin-1 は血管内皮細胞浸潤能を濃度依存的（100 $200 \mathrm{ng} / \mathrm{ml})$ に増加させたが，高濃度（800 ng/ml）では 変化が見られなかった. また, netrin-1 はマトリゲル上 における血管ネットワーク形成 (2 次元培養) および 3 次元培養で sprouting を促進させた。ささらに netrin-1 をマトリゲルとともにマウス皮下に移植すると，ゲル 内にマウス血管内皮細胞を呼び寄せネットワークを構 築したため, netrin-1 が血管新生誘導因子であること が確認された。一方で，血管内皮細胞では neogenin レセプターが有意に発現していたため, neogeninに 対する中和抗体あるいは siRNAを処理したところ, netrin-1 による浸潤および血管新生誘導が抑制された。

\section{3）免疫応答，炎症}

これまでに netrin-1 が好中球やマクロファージの遊 走を制御していることが報告されている. 我々はDr. David M. Briscoe（Harvard Medical School）研究室と 共同でリンパ球への影響とその詳細なメカニズム解析 を行った．CD4 陽性 T細胞には，ネトリンレセプター neogenin, UNC5A，UNC5Bの発現が確認されたが, マイトジェン刺激を行うと, その発現が有意に増加し た. CD4 陽性 T 細胞に, netrin-1 処理を行うと遊走能 が立進したが，この反応には neogenin レセプターが 関与していることがノックダウン実験から明らかに なった．さらに免疫反応や炎症とのかかわりを明らか にするために，ヒト化マウスを用いた皮膚組織移植モ デルで検討を行った，皮膚片移植 7 日後に netrin-1 を 処置して，14 日後に移植組織を観察した。 その結果， netrin-1 処置群では移植片へのリンパ球浸潤がコント ロール群と比して増加していた。また浸潤していた CD3 陽性細胞の多くが neogenin 陽性であり，これは netrin-1 に反応した細胞が組織に浸潤したことを示唆 している，さらに心臟移植後に拒絶反応が見られたバ イオプシーサンプルを用いた検討でも同様に, 組織の 約 12\%に neogenin 陽性細胞が観察された。 以上のこ とから, netrin-1 と neogenin レセプターによる反応が 免疫・炎症応答に極めて重要であることが明らかと なった (27).

\section{5. ネトリンの分子メカニズム解析}

\section{1）細胞骨格アクチン}

U87MG あるいは HUVEC に netrin-1 を処理すると， アクチン重合が促進してアクチンファイバー形成が増 加した。これはSEMA3Fで見られた現象と逆の作用 
であった。この netrin-1 による効果は RhoA 阻害薬 C3 transferaseで抑制されたことから，RhoA 経路の関与 が示唆される，そこで，RhoA 経路への影響をみたと ころ, netrin-1 処理によって RhoA が活性化（GDPか ら GTP 型に置換) され，その下流分子 cofillinのリン 酸化（不活性化）が観察された。

2) カテプシンプロテアーゼ

Netrin-1 処理によって細胞の浸潤能が充進したこと からマトリックスメタロプロテアーゼ (MMP) の関与 が考えられたため, MMP 阻害薬 GM6001 を処理した が効果は見られなかった。 そこでシステインプロテ アーゼ阻害薬 leupeptin を処理したところ netrin-1 によ る浸潤が抑制された。脳腫瘍ではカテプシンファミ リーの関与が報告されていたため, 様々なカテプシン 阻害薬を用いて検討を行ったところ，カテプシン B (CatB) 阻害薬が netrin-1 の効果を抑制することが分 かった. CatB は産生された後, リソソーム分画に局 在しているが，活性化したものが細胞膜上へ輸送され て細胞外基質を分解して浸潤, 転移に関与する. RhoA 阻害薬 C3 transferase を細胞に処理すると, netrin-1 による CatBの活性化と細胞表面への輸送を阻 害したことから, CatB は RhoA 依存的に制御されてい ることが明らかとなった。これらの検討から， netrin-1 がグリオーマ細胞の浸潤性を克進させる機序 として CatB が中心的な役割を担っていることが明ら かとなった.

\section{3) CREB}

さらに細胞内の詳細なメカニズム解析を行った. Phospho-Kinase Antibody Array（R\&D）を用いて検討を 行った結果, netrin-1 処理によって mitogen-activated protein kinase,（MAPK または ERK）と cAMP response element binding protein (CREB) のリン酸化が上昇し た. MAPK 阻害薬によって netrin-1 によって誘導され た CREB のリン酸化が抑制されることから，CREBは MAPK 経路を経て活性化することが分かった．CREB は転写因子として機能しており, 細胞の浸潤やがんの 転移に関与している。 そこでCREBを siRNAによって ノックダウンしたところ, netrin-1によって上昇した 浸潤性が抑制されること,さらに, CatB 発現が抑制さ れることが分かった。

以上のデータから netrin-1 は, MAPK 経路を介して CREB を活性化して CatB 発現を上昇させる。一方で, netrin-1 によって活性化した RhoA はアクチンファイ バー形成を促進するとともに, CatB を活性化して細 胞膜上へと移行させる。これによって細胞遊走, 浸潤 能が充進することが明らかとなった (図 $3 \mathrm{~B}$ 参照)。こ
A

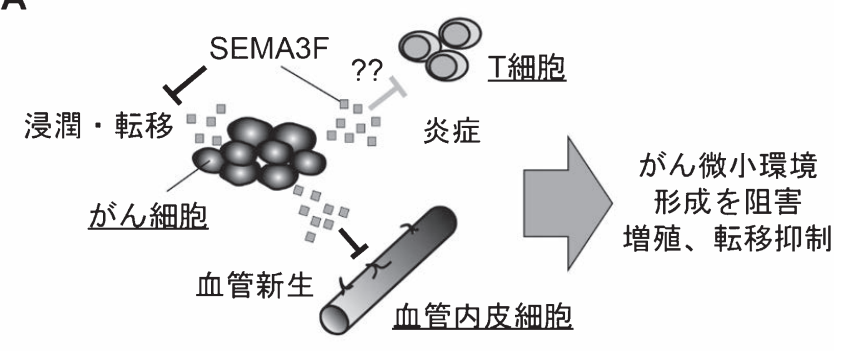

B

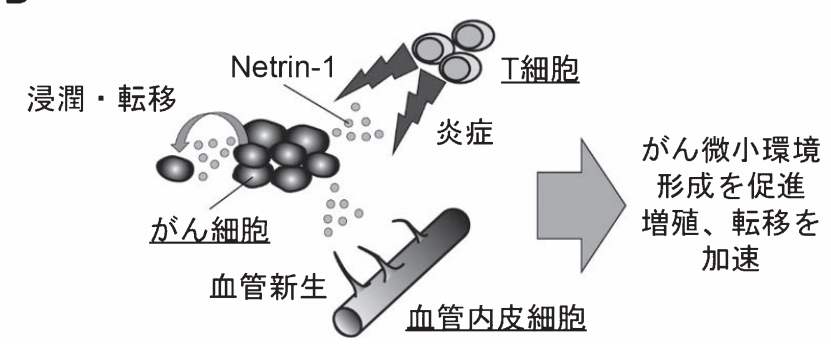

図 4 がん微小環境制御因子としての軸索誘導因子の役割 A : SEMA3F はがん細胞の転移, 血管新生を阻害する. (免疫細胞に対 する効果は現在解析中. ) 外部から SEMA3F を投与することによって, がん微小環境形成を阻害することが可能と考えられる. B : Netrin-1 は がん細胞転移, 血管新生を促進する. また免疫細胞を誘引して炎症を惹 起する. Netrin-1 とその標的しセプターを阻害することによってがん 微小環境形成を阻害できると考えている.

の現象はグリオーマ細胞のみならず，髄芽腫細胞でも 確認された.

\section{5. おわりに}

本稿では, 軸索誘導因子の神経系以外の役割に着目 してデータを紹介した。軸索誘導因子は，がん組織に おいてがん細胞のみならず血管内皮細胞, 免疫細胞, 間質細胞など周囲組織に影響を与え，がんの微小環境 を形成して, がん細胞の転移や浸潤性, 血管新生, 免 疫応答を制御していることが分かってきた。そこで 我々は軸索誘導因子を『がん微小環境制御因子』と捉 え, がん治療標的として解析を続けている. がん微小 環境は，がん幹細胞を形成・維持する幹細胞ニッチと 考えられており，がんの再発や薬剤耐性の原因とされ ており創薬標的として注目されている。 そこで軸索誘 導因子のがん微小環境制御因子としての詳細な機能を 明らかにして, 新たな抗がん薬としての可能性を提示 していきたいと考えている(図 4 参照).

著者の利益相反 : 開示すべき利益相反はない.

\section{文献}

1) Carmeliet $P$, et al. Nature. 2005;436:193-200.

2) Vesalius A. De humani corporis fabrica (On the Fabric of the Human Body); 1543.

3) Gerhardt H, et al. J Cell Biol. 2003;161:1163-1177.

4) Folkman J. Nat Rev Drug Discov. 2007;6:273-286.

5) Soker S, et al. Cell. 1998;92:735-745. 
6) Miao HQ, et al. J Cell Biol. 1999;146:233-242.

7) Ruiz de Almodovar C, et al. Neuron. 2011;70:966-978.

8) Luo Y, et al. Cell. 1993;75:217-227.

9) Neufeld G, et al. Nat Rev Cancer. 2008;8:632-645.

10) Worzfeld T, et al. Nat Rev Drug Discov. 2014;13:603-621.

11) Roche J, et al. Oncogene. 1996;12:1289-1297.

12) Xiang RH, et al. Genomics. 1996;32:39-48.

13) Bielenberg DR, et al. J Clin Invest. 2004;114:1260-1271.

14) Nakayama H, et al. Biochem Biophys Res Commun. 2015; 464:126-132.

15) Shimizu A, et al. J Biol Chem. 2008;283:27230-27238.

16) Procaccia V, et al. Biochem Biophys Res Commun. 2014;448: 134-138.

17) Nakayama H, et al. Sci Rep. 2015;5:11789.

18) Saxton RA, et al. Cell. 2017;169:361-371.

19) Mehlen $P$, et al. Nat Rev Cancer. 2011;11:188-197.

20) Park KW, et al. Proc Natl Acad Sci U S A. 2004;101:1621016215.

21) Wilson BD, et al. Science. 2006;313:640-644.

22) Larrivee B, et al. Genes Dev. 2007;21:2433-2447.

23) Lu X, et al. Nature. 2004;432:179-186.

24) Ramkhelawon B, et al. Nat Med. 2014;20:377-384.

25) Akino T, et al. Cancer Res. 2014;74:3716-3726.

26) Shimizu A, et al. J Biol Chem. 2013;288:2210-2222

27) Boneschansker L, et al. J Immunol. 2016;197:1389-1398.
著者プロフィール

中山 寛尚（なかやま ひろなお）

広島国際大学保健医療学部医療技術学科

臨床検査学専攻, 講師, 医療技術学博士.

$\diamond 2003$ 年名古屋大学医学部保健学科検査

技術科学専攻卒業, ’08 年名古屋大学大学

院医学系研究科医療技術学専攻病態解析学

分野修了, 08 年愛媛大学医学部生化学.

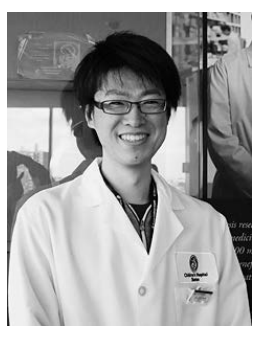

分子遺伝学分野研究員, '11 年 Boston Children's Hospital/Harvard

Medical School リサーチフェロー, 頭脳循環を活性化する若手研 究者海外派遣プログラム (愛媛大学より派遣), ’13 年日本学術振 興会海外特別研究員, '15 年愛媛大学プロテオサイエンスセン ター 助教, ' 17 年より現職. \研究テーマ：軸索誘導因子による がん微小環境制御メカニズム解析, 膜型増殖因子 EGFファミリー 分子の shedding 解析. 